\title{
Forensic Archaeometry Applied to Antiquities Trafficking: The Beginnings of an Investigation at the Frontiers of Knowledge
}

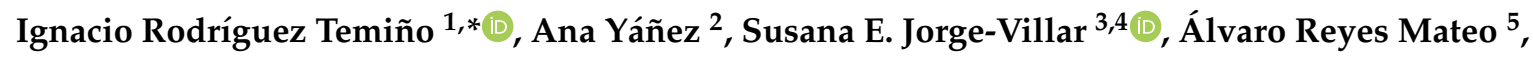 \\ Javier Rufino Rus ${ }^{6}$, Jesús Salas Álvarez ${ }^{7}$ and Ana Carmen Lavín Berdonces ${ }^{8}$ \\ 1 Department of Culture, Government of Andalusia, 41071 Seville, Spain \\ 2 Administrative Law, Faculty of Political and Social Science, Complutense University of Madrid, \\ 28040 Madrid, Spain; yannez@der.ucm.es \\ 3 Área de Geodinámica Interna, Facultad de Educación, Universidad de Burgos, 09001 Burgos, Spain; \\ susanajorgevillar@hotmail.com \\ 4 Centro Nacional de Investigación en Evolución Humana (CENIEH), 09002 Burgos, Spain \\ 5 Historical Heritage Brigade (Group II), Central Specialized and Violent Crime Unit, \\ General Commissariat of Judiciary Police, 28071 Madrid, Spain; cgpj.bpatrimoniohistoricog2@policia.es \\ 6 Provincial Prosecutor's Office of Seville, 41018 Seville, Spain; javier.rufino.ius@juntadeandalucia.es \\ 7 Department of Prehistory, Ancient History, and Archaeology, Faculty of Geography and History, \\ Complutense University of Madrid, 28040 Madrid, Spain; jessalas@ucm.es \\ 8 Royal Estate of Aranjuez, National Heritage, 28300 Madrid, Spain; acarmen.lavin@patrimonionacional.es \\ * Correspondence: ignacio.rodriguez.temino@juntadeandalucia.es
}

Received: 8 October 2018; Accepted: 29 November 2018; Published: 3 December 2018

check for updates

\begin{abstract}
For most of its history, archaeology has too often taken an indulgent attitude toward looting and antiquities trafficking. The primary response to these dangers has been to publish the main findings made outside of academia. As a result of this approach and the prominent role played by police techniques in investigating such crimes, investigations are primarily based on documentary research. This approach makes it harder to determine such essential factors in this field as an object's collecting history or discovery date. This paper proposes new ways of studying collecting history, drawing on research projects on the use of archaeometry to shed light on cases of looting or trafficking involving police, court, or government intervention; hence, its qualification as "forensic". Although the current state of knowledge does not enable the presentation of novel research, we believe that researchers and interested institutions should be made aware of the advisability of using archaeometry more directly in the fight against these scourges.
\end{abstract}

Keywords: antiquities trafficking; archaeometry; archaeological looting; expert evidence; judicial proceedings

\section{Introduction}

Throughout history, culturally valuable objects have been forcibly removed from the places where they were created to be taken elsewhere. The causes of these outflows-generally undesired by the populations stripped of the objects-have and continue to vary, depending on whether they are the product of armed conflict or peacetime practices. However, they invariably begin with acts of looting. The investigation of antiquities trafficking is thus inextricably linked to the looting from which it stems.

A detailed account of the state of the research on the fight against antiquities trafficking is beyond the scope of this paper. Readers seeking to further their knowledge of points not addressed here are encouraged to look to the extensive body of literature on various aspects of this type of crime. Our aim 
is simply to express our concern regarding the limitations of the traditional method of investigating both looting and antiquities trafficking when it comes to determining artifacts' illicit collecting history and provenience. ${ }^{1}$ This method is primarily based on the analysis of documents recovered in police investigations, including both private records and the documents required to launder the artifacts' illicit origin, along with accounts from informers and stylistic assessments that can help to pinpoint the artifacts' likely place of origin. Many recent police investigations have relied on this method, such as Operation Harmakhis, conducted by the Brigada de Patrimonio Histórico de la Policía Nacional (Spanish National Police's Historical Heritage Brigade) (see El País, 28 March 2018, “Dos detenidos en Barcelona por financiar al ISIS con arte expoliado en Libia" [Two arrested in Barcelona on charges of financing ISIS with looted art from Libya]). As a result of that operation, two people, Jaume Bagot Peix and Oriol Carreras Palomar, were charged with financing terrorism, membership in a criminal organization, dealing in stolen goods, smuggling, and document forgery in connection with the trafficking of antiquities from various cities of ancient Cyrenaica (Libya). In this case, the distinctive features of the funerary sculptures from the region (Belzic 2017), on which the aforementioned criminal charges focus, enabled a plausible ascription of their provenience. The Spanish National Police then requested assistance from the Libyan authorities to confirm the authenticity and origin of the investigated pieces. Their provenience in the Apollonia and Cyrene sites, two necropolises in the Cyrenaica region known to have been looted by terrorist groups, was thus accredited. Additionally, some of the pieces had been damaged and bore marks indicating they had been forcefully extracted from the subsoil. For other objects seized in the operation, however, such a typological attribution is more complex.

As we will see, the reasons for concern are diverse. First, these investigations are intrinsically selective, for they can only be carried out in cases in which documents have been created for the primary purpose of laundering the artifacts' provenience, i.e., when the aim is to sell the illicitly acquired objects on the generally more lucrative licit market. Obviously, that is only done with important artifacts, true works of art. Most looted archaeological objects, however, are not so spectacularly unique; they are thus sold directly on online auction sites with little or no documentation at all (Brodie 2015b). Second, current customs controls, especially within European countries, hardly pose an insurmountable barrier, especially for artifacts up for sale that have not been declared as antiquities and are shipped via forwarding agents (González-Barandiarán y de Muller 2008). Finally, as will be shown, this document-based method of investigating, which is largely focused on document forgery, has significant limitations.

In light of these considerations, we believe that archaeometry, i.e., the analytical arsenal of the natural sciences, could potentially be used in evidentiary practice, in both administrative and judicial proceedings related to archaeological looting and the illicit trafficking of cultural goods; to date, its use has been limited to efforts to authenticate archaeological objects with a view to detecting potential fakes (Goodall 2012). Furthermore, not only should existing techniques be applied, but new research should be undertaken to determine the origin of artifacts seized in police operations and, especially, to develop methods that would enable a reliable estimate of the date on which those objects first came to light after centuries spent underground or underwater.

1 In the case of artifacts that have not been subjected to an archaeological autopsy, there is a certain disparity in the terminology used to refer to the concept of what in Spanish is called procedencia. This is because it encompasses two distinct realities: The site or stratigraphic location and the list of successive owners. The most common terms in English are "provenience" and "provenance," as established by Coggins (1998, p. 65). Both terms are used both by archaeologists (Brodie 2011) and chemists (Price and Burton 2011, p. 213 ss.). Chippindale and Gill (2000) changed "provenance" to "collecting history". Similarly, the Association of Art Museum Directors (AAMD 2013) uses the term "ownership history" instead of "provenance". By contrast, Myren (2010) uses the pair of terms "origin" and "provenance". More recently, Marlowe (2016) referred to these two concepts with the terms "grounded" and "ungrounded", to distinguish between artifacts whose collecting history is known and those for which there are doubts. In this paper, in order to facilitate overall comprehension, we will use "provenience" to indicate the place of origin of a given archaeological object and "collecting history" to refer to the list of its successive owners. 
In fact, in its Operational Guidelines for the Implementation of the Convention on the Means of Prohibiting and Preventing the Illicit Import, Export, and Transfer of Ownership of Cultural Property (UNESCO, Paris 1970), a seminal document in the fight against antiquities trafficking, UNESCO itself recognized the need for the signatory states to promote these types of analyses:

States Parties may support their requests for the recovery and return of cultural property which is unlawfully excavated or lawfully excavated but unlawfully retained in another State Party to the Convention, with reasonable scientific reports, results of scientific analysis or experts' evaluations on provenance of the unlawfully excavated property.

Considering the difficulties of conducting research for retrospective evidence, States Parties are strongly encouraged to consider accredited scientific studies and analysis as evidence.

From this perspective, it is surprising that archaeometry has hardly been used in the investigation of antiquities trafficking, except, as noted, in the identification of fakes. One possible explanation for this gap is the traditional lack of real involvement by archaeologists in the fight against the trade in objects of unknown origin. Interest in the academic publication of such pieces has played an enabling role in downplaying and sugarcoating the horror of illicit digs and the resulting loss of context (Wiseman 1984; Enríquez Navascués and Jiménez 2005; Renfrew 2000, p. 10; Brodie and Renfrew 2005; Brodie 2011). In fact, many archaeologists dedicated to the study of illicit trafficking seem to be more comfortable working at criminological research centers than archaeological ones (Brodie 2015a). In short, archaeometry seeks and offers responses to questions and quandaries arising from archaeological research. As no questions have been posed with regard to this issue, except in relation to the verification of fakes, no valid answers have been generated for the fight against illicit trafficking, except again in relation to the verification of fakes.

We call the application of these new archaeometric techniques to the investigation of crimes related to looting and antiquities trafficking "forensic archaeometry". This term is rare in the academic literature of both archaeology and the forensic sciences. It is rarer still in the literature on antiquities trafficking. A brief explanation of the meaning with which we use it here would thus be helpful.

The definition sensu lato of archaeometry is not particularly problematic. It refers to the field of research characterized by the application of methods from the natural sciences to solve questions of an archaeological nature. In other words, it is used to learn more about past ways of life through the study of material culture, as well as the conservation and restoration of archaeological objects (Edwards and Vandenabeele 2012).

By contrast, the term "forensic" does require clarification in this context, to distinguish how it is used here from other common definitions it may have in our line of work. Initially, forensic archaeometry might seem redundant, given the existence of other subdisciplines, such as forensic archaeology (Hunter and Cox 2005) or forensic geology (Pye 2007), involving research that combines archaeological, anthropological, or geological methodologies with the forensic sciences. In those cases, the adjective "forensic" is used to denote a specific purpose related to the investigation of criminal acts resulting in the violent loss of human life in recent times. What sets forensic archaeology apart from other archaeologies of death is the fact that it is used in the investigation of acts that could potentially give rise to moral or criminal responsibility on the part of the perpetrators. The term "forensic archaeometry" is used in this same sense in the only other paper that, to our knowledge, uses the phrase (Bower et al. 1993).

This is relevant because, in the present case, archaeometric investigation should also culminate in a report to be used, in particular, as part of a police inquiry and, subsequently, as evidence at a trial or in civil, administrative, or criminal proceedings. However, in this paper, the use of the term "forensic" is entirely unrelated to crimes against people. Rather, we are using it in a different, broader sense, related to the use of the scientific method to shed light on other types of criminal behavior. Specifically, we are interested in looting and antiquities trafficking. The adjective "forensic", in the sense with which it is used here, is also used to describe archaeologists whose research focuses on antiquities trafficking. 
"Forensic archaeometry" runs parallel to investigations of a historiographical nature that, in the case of Spain (as well as other countries with similar systems for authorizing archaeological activities), can yield pertinent data for establishing the legality or illegality of the origin of an archaeological piece.

There are not yet any proven and reliable investigation methods capable of producing incontrovertible conclusions in this area. However, we are convinced that the future of investigations in this branch of cultural crime lies in dedicating time and resources to developing specific techniques and establishing their reliability.

The authors of the present paper are professionals either directly involved in the fight against looting or with extensive knowledge of the state of the research in concomitant disciplines that we believe could be useful to advancing on this task. As a result of this conviction, we have jointly participated in several research projects, such as the R and D project "DER2016-74841-R: Instrumentos jurídicos en defensa de la integridad de los bienes arqueológicos" (Legal Instruments in Defense of the Integrity of Archaeological Heritage), funded by the Spanish Ministry of Economy and Competitiveness for the 2017-2019 period. We have also submitted a proposal to the $2018 \mathrm{H} 2020$ Marie Skłodowska-Curie Innovative Training Networks (H2020-MSCA-ITN-2018) call for projects, namely, the ARCHGEOLOOT project, led by the University of Burgos, together with other European universities and institutions. The main objective of ARCHGEOLOOT is to train a new generation of researchers to develop innovative procedures for determining the material, site, and excavation date of looted archaeological objects. These procedures will be based on a set of new forensic archaeometry methodological protocols and use advanced data-mining and machine-learning tools. Specifically, the project aims to facilitate the development of an innovative scientific protocol based on custom-designed software tools for identifying the provenance of archaeological artifacts, as well as a new methodology for measuring the time lapse between the excavation and police seizure of plundered archaeological pieces.

The line of research we are opening has a clear procedural use and directly affects police investigation techniques related to the trafficking of artifacts that have been illicitly excavated or removed from a country. It has the potential to be a substantive-and, we hope, influential一type of expert evidence that will enable progress in this field. One of the main challenges of the aforementioned projects is for the developed techniques to be easy to apply and not to require costly equipment so as to facilitate greater implementation throughout the network of forensic police labs that exist in all developed countries. At the same time, we understand that the results of this research will be more widely disseminated if they can be used by museums, auction houses, antique dealers, and other stakeholders who may be affected by the irregular trafficking of cultural artifacts, especially in terms of their collecting history.

Spain is possibly one of the countries in Europe to take the fight against archaeological looting most seriously, employing both administrative and criminal proceedings (Yañez and Rodríguez Temiño 2018). Consequently, in this paper, we pay special attention to the debate arising as a result of police investigations in the country into the trafficking of antiquities looted from archaeological sites. However, this phenomenon is obviously not limited to Spain, but rather is international in scope. Indeed, establishing as unambiguously as possible the provenience and collecting history of objects suspected of having been looted or stolen and illegally removed from their countries of origin has emerged as a key factor for applying the international rules governing such cases. These rules are well known. Nevertheless, in this paper, we take a deeper look at their relationship with the applicable choice-of-law rule (lex rei sitae vs. lex originis). Although this aspect is usually neglected in the literature on illicit trafficking, it is of enormous importance in practice, and its relationship with the provenience of the object in question is crucial. Here, we borrow from Manacorda (2009) and refer to these different rules as "Laws". This is because they are legal milestones that transcend the mere text of the adopted international legal instrument itself to gather, into a single whole, the full range of "formants" that make up the legal order they embody (Pegoraro 2013, p. 258). 
Nevertheless, as not everything depends on evidential contingency, a legal regulation is required to combat this form of trafficking that is more conducive to the potential recovery of antiquities that are illicitly removed and sold. The paper thus concludes with several proposals to this end.

We are aware that we are embarking on a long and complex path with no certain end. We would like to follow it, but our team alone cannot cover it all. Therefore, this paper is also intended as an invitation to colleagues to explore this new avenue of research as well, from other vantage points, and to build networks to enable coordinated work on it.

\section{The (Deficient) International Response to Antiquities Trafficking}

There is a long tradition of condemning acts of violent appropriation of vestiges found in other places. The plundering by Lord Elgin and the philhellenic Xenion society drew angry criticism from the foreigners who witnessed the vandalism with which it was carried out (Thomasson 2010). Around the same time, after the Congress of Vienna, Antonio Canova sought to repatriate to the Italian states the works of art seized by the French armies (Scovazzi 2015, pp. 26-46). This trend was enshrined as an extension of humanitarian law, the cornerstone of which remains the Convention for the Protection of Cultural Property in the Event of Armed Conflict (The Hague 1954) and its two protocols, the first signed in the same year and the second in 1999. However, the international community has not only responded through law. Other measures have also been taken to better combat looting and the illicit trafficking of cultural objects, in general, and of antiquities, in particular.

\subsection{The International Legal Response: Reevaluating What Is Criminal}

In the second half of the last century, the international community's response to concern over the looting and illicit trafficking of antiquities took the form of three significant conventions and their implementation. The first is the aforementioned Hague Convention ("Hague Law"). It was followed by a second turning point, represented by the Paris Convention of 1970 ("Paris Law"), and a third, represented by the 1995 UNIDROIT Convention on Stolen or Illegally Exported Cultural Objects ("Rome Law").

Although it is not a single regulatory text, we would expand this list to include "Brussels Law", the set of norms for combating the illicit trafficking of cultural objects applicable in EU countries. European authorities continue to use civil measures to sanction illegal flows of cultural objects. The competent authorities of member states into which cultural objects unlawfully removed from another member state are introduced are required to order their return on the grounds of breach of the rules for the protection thereof. This initiative was formalized in the adoption of Council Directive 93/7/EEC of 15 March 1993, amended by Directives 96/100/EC and 2001/38/EC of the European Parliament and the Council, and repealed and replaced by Directive 2014/60/EU of the European Parliament and of the Council of 15 May 2014, on the return of cultural objects unlawfully removed from the territory of a member state and amending Regulation (EU) No 1024/2012 (Recast). The interest in including a separate reference to "Brussels Law" lies in the fact that, as opposed to "Paris Law" or "Rome Law", in the context of the EU, lex originis is the choice-of-law rule. This is a special conflict rule that, unlike the general and neutral lex rei sitae rule, is substantively oriented toward subjecting the proprietary rights (not any real right) to cultural objects of special relevance to their state of origin (not any object) to the law of that state for the purpose of facilitating their return (Fuentes Camacho 1994). "Brussels Law" is thus included here because this distinction is of enormous importance to the future of the fight against looting and antiquities trafficking. In the sphere of private international law, the lex rei sitae rule is applied to solve the problem of mobile conflicts arising from a change or changes in an object's location. The most widely used solution to this problem is for the proprietary rights to the object to be governed by the law of the place where it was originally located until such time as there is an official change in its status resulting from a legal transaction of real significance (in the cases analyzed here, acquisition by a third party), at which point the new lex rei sitae displaces the old one (Fuentes Camacho 1994). 
A detailed discussion of these rules of international law or those governing transnational relations between states and museum institutions or private collections falls beyond the scope of this paper. We would simply underscore the traditional orientation of international and European regulations toward private law instruments, i.e., toward the return or restitution of the object, rather than toward criminal law, which is reserved for sanctions in the anomalous cases of armed conflict (Manacorda 2011; Lazari 2018).

This rejection of a criminal law approach explains why the European Convention on Offences relating to Cultural Property, opened for signature in Delphi in 1985, has not played a significant role; it has failed to attract enough signatories to enter into force. However, this does not mean that the civil approach represented by the Paris and Rome laws has been truly effective. On the contrary, it is widely recognized in the literature that this panoply of regulations falls short (Gerstenblith 2003; Manacorda 2011; Mackenzie 2011). The difference in the political weight of the countries that receive objects and those that supply them, the complexity of domestic laws for the purposes of private law, as it is not always easy to determine which rule of law is applicable to a given object (Fuentes Camacho 1994), and the techniques for covering the trail regarding the objects' origin all hinder and prolong the processes, rendering them all but exceptional. In short, the recent international reality shows that civil actions to achieve the return of pieces are only undertaken when very significant objects of great economic value, able to justify the cost of the judicial proceedings, are at stake.

In light of the most recent police cases, we are currently witnessing the repositioning of criminal law approaches in a preferred spot within the range of international actions, rescuing them from their limited application in extraordinary cases, such as in armed conflicts. This new development is not the result of an explicit recognition of the ineffectiveness of the civil measures, but rather-as noted by Manacorda (2011) — of the very complexity of the criminal organizations operating in the transnational theater.

Undoubtedly, another cause of this embrace of a criminal law approach is the impact of the wave of aggressions against cultural goods by Salafi jihadists (i.e., members of a strictly orthodox Sunni Muslim sect advocating a return to the early Islam of the Koran and Sunna). Proof of this can be found in two recent international developments. The first is Resolution 2347 (2017), adopted by the UN Security Council at its 7907th meeting, on 24 March 2017, which condemns the destruction and theft of cultural objects from areas of armed conflict. The second is the recent opening for ratification by the Council of Europe of a new Convention on Offences Relating to Cultural Property (Nicosia 2017) that, in its own words, "fills a gap in international law, since none of the existing conventions deal with criminal law issues." The Council of Europe does not hide its concern over the armed conflicts in the Middle East, as clearly expressed in the Explanatory Report accompanying the Convention:

In the run up to the drafting of the Convention, Western markets saw a major increase in the number of looted and stolen antiquities, most notably from important sites in Iraq and Syria in connection with the breakdown of law and order in those countries. Non-state armed groups and terrorist organizations were involved in the destruction and plundering of ancient sites in order to finance their belligerent operations.

An important step has also been taken in this regard in the context of the law applicable in cases of armed conflict, albeit in the opposite direction. That law has dealt with the destruction of cultural property as a war crime, in a clear response by the West to the Salafi jihadist groups' provocations. In our view, the so-called al-Mahdi affair should be interpreted this way. This case involves the recent conviction by the International Criminal Court (ICC) of Ahmad al-Mahdi for his involvement, as a prominent leader of Ansar Dine (a terrorist organization associated with Al Qaeda in the Islamic Maghreb), in the destruction of ten shrines and mosques in Timbuktu. In Judgment No. ICC-01/12-01/15, of 27 September 2016, for the first time, that court ruled that such actions should be classified as war crimes (San Martín Calvo 2016; Gutiérrez Zarza 2017). This is quite significant given that, as has been noted (Frulli 2011), the ICC Statute follows retrograde criteria in this matter compared to those supported, for example, by Protocol II to the Hague Convention ("Hague Law"). 
However, the destruction and attacks caused by Western armies, such as those occurring during the invasion of Iraq by the U.S.-led international coalition (Farchakh-Bajjaly 2008), will go unpunished.

In short, the looting and the illicit trafficking of antiquities should be approached as endemic problems for which there are no simple or easy solutions. Not even those proposals that have been postulated as compromises between protectionism and a free-market approach (O'Keefe 1997, p. 63 f.) have achieved widespread recognition or proven able to control archaeological looting. It is a complex phenomenon fed by political, market, and social dynamics grounded in the unequal distribution of wealth at the global scale and the consequent subordination of poor countries to those with healthier economies. While more incisive proposals aimed at reducing the illicit market for antiquities (Mackenzie 2011) lack support, UNESCO seems to be focused on strengthening the mechanisms implemented under "Paris Law", returning to them in its aforementioned Operational Guidelines. This line of action, however, does not seem to be incompatible with strengthening the criminal law approach. The future of the new Council of Europe convention will tell us whether or not the time has come to add a new milestone to international law for combating illicit trafficking, "Nicosia Law".

\subsection{Operational Responses}

The response of the international community has not only taken the form of the pertinent legal regulations. The concern generated by the loss of objects due to illicit trafficking has given rise to numerous other initiatives as well, by both public institutions (UNESCO, Interpol, the European Commission, the EU, World Customs Organization) and associations (International Council of Museums (ICOM), International Council on Monuments and Sites (ICOMOS), Trafficking Culture, etc.). The issue has also captured the attention of a wide range of researchers, who have produced a substantial body of literature on the matter, fortunately well known by those of us who work in this field, the mere enumeration of which would require a paper of its own.

As a result of this interest, some bodies have designed and implemented tools to facilitate the conveyance of information and the traceability of objects. This work is similarly well known. Examples include the databases of stolen objects managed by Interpol, the various UNESCO regulations, the ICOM Red Lists, and two proposals to document works of art with a view to their exportation: Object ID, by the J. Paul Getty Trust (1997), which has been endorsed by ICOM, and the UNESCO-WCO Model Export Certificate (2005), although the latter has been only irregularly implemented by European countries (Armbrüster et al. 2011).

There is little doubt regarding the benefit that these initiatives have, not only for preventing and combating the illicit trafficking of cultural objects, but also to raise awareness of the damage caused to the cultural wealth of the countries where they are located and, by extension, to the international community as a whole. Nor is there much doubt that this mass of information needs to be sorted and classified to make it easier to search. Indeed, the ICOM has undertaken efforts in this regard with its International Observatory on Illicit Traffic in Cultural Goods, although that platform ceased to be updated around 2015. On an individual basis, various organizations maintain news feeds on social media sites such as Twitter or Facebook, dedicated to press items related to the illicit trafficking of cultural objects.

However, the lack of stable administrative structures linked to international organizations with responsibilities in this matter prevents a truly fruitful coordinated effort. Such an effort should go beyond the mere gathering of information and news to transform that knowledge into intelligence. That requires a type of knowledge engineering that has not yet been used on these types of platforms and that, to date, no one has considered.

Another of the main tools for guiding the behavior of the institutions, companies, and professionals involved in or related to the licit trade in cultural goods and, in particular, the licit trade in antiquities, is codes of ethics and catalogs of best practices. Most of these are in keeping with the provisions of "Paris Law". However, it is painfully obvious that the commitments to ensure that acquisitions abide by these codes of ethics are voluntary. In any case, there is no higher authority to 
require compliance or impose consequences for breaches. No museum, for example, has been asked to leave any organization for failing to adhere to its code of ethics with regard to the acquisition of objects of unknown origin (Gerstenblith 2003). Furthermore, the codes themselves tend to be drafted in ambiguous terms, with numerous phrases that lend themselves to loose interpretations, such as the concept of "due diligence" that acquirers are supposed to exercise as proof of their good faith. When the Guidelines of the Association of Art Museum Directors (AAMD), which includes approximately 167 of the most important museums in the U.S., have to refer to the country of possible origin of an unlawfully removed object, they use the term "probable country of modern discovery". They thus avoid explicitly recognizing that country's proprietary rights, in keeping with the theses of Merryman (1994) and Cuno (2007).

Each new scandal or return made by a famous museum is immediately followed by the announcement that it will review its code of ethics to strengthen its protocols, which, according to the standard narrative, fell short. However, the reforms are never as far-reaching as one would hope. The AAMD Guidelines (AAMD 2013) are a paradigmatic case. In the 2004 version of these Guidelines, the association advised museums faced with the challenge of proving the certain origin of a piece to acquire it, provided it could be established that the piece had been outside the country of supposed origin for a period of 10 years (Kaye 2009, p. 418 f.). In 2008, that possibility was eliminated, although the Guidelines continued to provide for certain exceptions that enabled the object's acquisition. The 2013 version lightly touches on the matter of transparency in exceptional acquisitions of goods without guarantees of legality, an aspect that had been widely called for (Brodie 2011), noting that they should be posted to the AAMD's website, along with an explanation of the basis for the acquisition decision. This studied ambiguity stems from the tacit need that museums have to continue acquiring remarkable pieces to strengthen their exhibit offer. Such objects cannot be acquired through the legal trade. Codes of ethics must thus walk the tightrope of this tension between the moral obligation of ethical conduct and fear of what museums consider a stagnation in the renewal of the exhibit offer.

\section{The Problem of Objects with No Known Provenience or Collecting History}

In reality, this section addresses not a single problem, but various issues that are intimately linked. On the one hand, it looks at the treatment of objects that lack an accredited provenience and/or whose collecting history is likewise unknown (the two circumstances often go hand in hand). However, it also examines the trend, primarily in purchasing countries, toward establishing the date of 1970, the year the "Paris Law" was published, as a red line of non-retroactivity for the acquisition of objects unlawfully removed from a country.

\subsection{Connivance with Private Collecting}

Throughout virtually its entire history, archaeology has treated the study of objects of unknown origin as normal. This may be due to the central role that such objects have played in the study of the past, despite the epistemological changes undergone by the discipline. Or it may be due to the vestiges left by the colonial tradition of a certain tolerance of relocation and-why not say it? - a feeling of Western superiority over developing countries. This would be in addition to the indifference, when not outright tolerance, with which private collecting has long been regarded (Muscarella 2009).

In this latter regard, it is worth recalling, for example, that Colin Renfrew (1991, p. 14) had no qualms in the early 1990s about studying Nicholas P. Goulandris's private collection of Cycladic idols, going so far as to praise the sensitivity, courage, and intelligence of Dolly Goulandris in preventing the pieces from being scattered on the international antiquarian market. In fact, as was later explained (Gill and Chippindale 1993, p. 604), Mrs. Goulandris's collecting zeal stirred up the market and thus encouraged more looting.

In Spain, the weakness of the legal-administrative framework to protect the country's vast archaeological heritage prior to the 1990s (Fernández Gómez 1996), when the autonomous communities were equipped with specialized personnel, led to the creation of private collections of archaeological 
artifacts acquired through the extensive looting that resulted from the popularization of metal detectors (Rodríguez Temiño 2012). One of the largest collections was surely the so-called Ricardo Marsal Archaeological Collection, which, by the mid-1990s, had grown to include more than 140,000 pieces (Rodríguez Temiño 2012, p. 90 ff.; Ojeda Calvo 2014; Guasch Galindo 2018). Marsal was not aware that he was doing anything illegal, as his goal was to prevent the removal and dispersion of the finds. However, in this case, too, there is no denying that his acquisitive activity served to encourage more looting throughout the Guadalquivir Basin. His collection was very well known among archaeologists, and some of the most interesting pieces were the subject of publications (e.g., Bendala Galán et al. 1993). However, it is also true that, at the time, the Andalusian government was being lobbied to legalize the collection (Rodríguez Temiño 2012, p. 95).

In reality, the collecting of archaeological artifacts in Spain remains a little-known phenomenon. At the time of writing, the Brigada de Patrimonio Histórico (National Police's Historical Heritage Brigade) is completing Operation Fiesta. The operation has led to the seizure of almost one thousand archaeological objects, many of which were looted, from a collector who had been amassing them for more than forty years. Like Goulandris and Marsal, this person is considered a sensitive connoisseur of antiquities even by scholars due to his numismatic collections, some of which had been acquired by the Museo Arqueológico Nacional (National Archaeological Museum) (Canto García and Francisco Olmo 2006). However, the more the objects seized by the Brigada de Patrimonio Histórico due to their presumably illicit origin are analyzed, the more it seems like the collection of objects he possessed was more the product of the ability of intermediaries to persuade him to buy than of any actual knowledge or taste for antiquities. In an unusual turn of events for Spain to date, at least on such a massive scale, a large part of the artifacts acquired by this individual as genuine ancient works of art have proven to be crude reproductions that can be purchased online or have been made for the express purpose of passing them off as originals.

Although the investigation has not yet concluded, this discovery not only exposes a certain capricious or compulsive character typical of hoarders, one of the most common profiles in this field (Subkowski 2006), but also the difference between acquiring pieces directly from looters and doing so through intermediaries. While the former may lie about the provenience of the objects in order to avoid publicizing places where they hope to find more, the artifacts they offer are genuine. The latter, on the other hand, may combine the commissive dynamic of their activity with other criminal behaviors, such as fraud, taking advantage of their buyers' deep ignorance of antiquities. This collection stands in contrast to others, such as that of Ricardo Marsal, who acquired the entire set of objects resulting from the looting and required his suppliers to provide explanations and drawings of the place of discovery as well (Gómez López 2014).

\subsection{The Debate between Objects and Context}

Despite this climate of connivance with private collecting by the academic and museum worlds, some voices have always sounded the alarm with regard to the disastrous consequences for knowledge entailed by antiquities trafficking, as it is fueled by looted pieces of uncertain origin. The effect becomes appalling in the case of a collusion of interests between collectors and museums (Gollin 1974).

One of the main points of concern was the tolerance, or lack thereof, for publishing pieces of unknown or uncertain origin. Muscarella (1977) studied this problem and its consequences in the specific case of the region of Ziwiye, in northeast Iran, the birthplace of Scythian culture. The discovery, in 1947, of a set of gold objects in that region sparked an avalanche of new finds said to have been made in that area. These were shortly joined by fakes imitating the style of the originals. These attributions, accepted by professionals, became part of the literature, such that the theories on the origin of Scythian culture began to be filled with Urartian, Phoenician, Cimmerian, Assyrian, and Greek influences, sowing confusion among scholars. The reasons identified by Muscarella combine, on the one hand, the interest for antiquarians and intermediaries of attributing an origin related to the Ziwiye treasure to the pieces, and thus increasing their value, even though the origin was false, with the voraciousness 
of archaeologists to publish new discoveries. Gill and Chippindale (1993) published a similar critique in relation to the Cycladic idols.

Wiseman (1984, p. 75) sagely noted that the practice of accepting attributed origins affords researchers a certain comfortable distance from the appearance of new looted objects on the market. No one can deny that an aseptic attitude, based on supposedly neutral morals, actually vindicates, even if indirectly, collectors and antiquarians. It also increases the price of these objects, for having caught the attention of archaeologists who have considered them worth publishing.

Although this dilemma regarding publication is far from over, it has been joined by another area of conflict: The differences between archaeologists and museum professionals with regard to the appraisals of archaeological artifacts. This has become one of the battlegrounds to witness some of the most heated debates.

As we have seen, the differences in opinions between the two types of professionals date back some time, to at least the appearance of the "Paris Law". However, the Italian police operation that exposed the plot of looting, smuggling, and illicit trafficking of antiquities known as the "Medici conspiracy" (Watson and Todeschini 2006), leading to the indictment of, among others, Giacomo Medici, Robin Symes, and Robert E. Hecht (intermediaries), as well as Marion True, the curator of the J. Paul Getty Museum, coupled with the processes of repatriation of objects illicitly exported from other countries that had been acquired by museums and private collections in the U.S. (Slayman 1998; Curtis 2006; Rhodes 2007; Felch and Frammolino 2011), put the matter on the table.

In fact, the debate over the issue is twofold. First, there is the debate between archaeologists and certain museum professionals, usually curators or directors of large European or North American museum institutions. Second, there is the issue of repatriation. While the "Parthenon Marbles" case is certainly the standard bearer (Fincham 2013), the issue can be extended to include many other flagship pieces currently held by major European and North American museums that have been claimed by their countries of origin. To some extent, there is a certain overlap.

In the first case, the two sides disagree on the material and intellectual consequence (i.e., for knowledge of the studied ancient civilizations) of the looting and acquisition of objects of uncertain origin. On the one hand, the advocates of private collecting (Ortiz 1994; Boardman 2006; and Cuno 2007 would be representative of this option) base their legal argument on the universality of human history, as defended by Merryman (2000-2001). They argue that art is not linked to any specific country, that the descendants and heirs of the great cultures of the past are all humanity, and, therefore, that the restrictions on exports imposed by countries in application of domestic laws are contrary to this universality and, in any case and in view of the facts, inefficient. The free movement of objects would allow museums to be places of education and inspiration. To fulfill that function, new acquisitions need to be made. In this view, archaeological heritage does not belong to modern-day nation states; its creators predate the emergence of these historical entities in the 19th century.

Furthermore, the antiquities market does not agree that the lack of a known origin is proof that an object was stolen. Collectors and antiquarians believe that the vast majority of pieces with an unknown provenience and collecting history are the result of chance finds in countries where ownership of the pieces in such cases is claimed by the state. In those cases, it is more beneficial to sell the pieces on the black market than to give them to an inefficient bureaucracy for a sometimes risible price. Logically, the information on the provenience and former owners is lost in the process (Ortiz 1994). Another case cited to justify lack of knowledge of an object's provenience or collecting history is when the object was found prior to the establishment of restrictions on the acquisition and exportation of antiquities in a given country (Wessel 2015).

Archaeologists, on the other hand, have gone from denouncing the looting of sites to studying the illicit trade in antiquities, the natural outlet for looted artifacts (Renfrew 2000; Brodie 2006), and the complicity of professionals in this trade (Muscarella 2009; Brodie 2011). The crux of the matter lies not in the confrontation between a view that advocates a free-market approach to antiquities and another that calls for the imposition of a more restrictive national and international legal framework 
in the name of nationalism or cultural purity, but rather whether or not illicit trafficking encourages looting. As Rosenberg (2007, p. 29) wrote in response to Cuno's (2007) thesis, " ... the crucial question is not who owns things but how one can ensure that the kind of information which can only be extracted from objects in context is not lost." And it is clear that trafficking does indeed encourage looting; in fact, it is the fuel that feeds that machinery. For Gerstenblith (2003), museums that acquire objects of doubtful or unknown origin are breaching their fiduciary obligations to the rest of society. Brodie and Proulx (2014) write of a "criminogenic museum culture" as a consequence of competitiveness and the spectacularization of culture to which it leads. As already noted several times, without new pieces, without masterpieces with which to put together groundbreaking shows, these institutions would not meet the expectations set for them. In that context, the traceability of a piece's origin is virtually irrelevant. Nor do codes of ethics impede this acquisitive dynamic.

In reality, this debate hides a fallacy. Those who present themselves as spokespeople of the world of museums are actually the directors of a certain type of museum, characterized by a cut-throat competitiveness to attract attention. Some of these institutions published a manifesto, the Declaration on the Importance and Value of Universal Museums, in 2003 (DIVUM 2004), in which they presented themselves not only as the bastions of universal history, but also as universal themselves, glossing over the fact that all museums share that trait.

Those institutions have been responsible for turning museums into a mass spectacle visited by thousands of tourists eager to engage in cultural consumerism. This is not the place for an in-depth discussion of this topic. Suffice it to note that their vision of objects is strongly influenced by a view of art history already in decline. These museums are interested only in flagship pieces, pieces ideally suited for exhibition, against an expensive and gimmicky backdrop. Needless to say, they have no interest in the hundreds of thousands of objects and samples that crowd the store rooms of thousands of museums the world over. However, history is written with the entire material record produced by excavations, not only artistic masterpieces. Moreover, one should be wary of any history told solely based on such exceptional objects.

Logically, this reality is not expressed so crudely; it is masked by subtler arguments, such as the universality of the objects and the educational function of the museums that hold them. Unsurprisingly, in terms of principles, the AAMD reserves the top spot in its aforementioned Guidelines to state its belief that "the artistic achievements of all civilizations should be represented in art museums, which, uniquely, offer the public the opportunity to encounter works of art directly, in the context of their own and other cultures, and where these works may educate, inspire and be enjoyed by all. The interests of the public are served by art museums around the world working to preserve, study and interpret our shared cultural heritage".

\subsection{The Debate over a Date}

The main codes of ethics, which affect museums from Western and North American countries, have adopted the date of 1970 as the threshold beyond which due diligence must be used to verify the certain and licit origin of acquired pieces, in application of Articles 7 and 21 of the "Paris Law". This tacit agreement has likewise been followed by many archaeologists (Renfrew 2000; Brodie et al. 2000; Chippindale and Gill 2000), practically without debate. In reality, the Convention entered into force in 1972, and, in practice, should only be applied between two states when it is in force for both. The advocates of this date argue that objects that entered museum institutions prior to it should be safe from claims.

Contrary to what is usually assumed, the "Paris Law" does not aim to consecrate any particular date. According to the Operational Guidelines, which interpret the meaning of the Convention, the non-retroactivity of international laws (ex Article 28 of the Convention of Vienna (1963) on the Law of Treaties) does not mean that the Convention seeks to legitimize earlier illicit transactions, or to limit the adoption of other legal instruments to enable the restitution or return of objects acquired prior to that date. As has been noted (Nafziger 1983-1984), there is a moral obligation to return the 
objects that has not diminished; a separate issue is whether the will exists to fulfill it, and the idea that 1970 should be adopted with a binding nature as the limit for requiring the return of pieces is being spread with considerable self-interest. The dispute between the United Kingdom and Greece over the "Parthenon Marbles" inevitably comes up in this controversy, although other historiographical reasons can be cited to justify the continued presence of the set at the British Museum (Fincham 2013).

Here, it is once again necessary to highlight the difference in the overall positions of recipient countries and those that have been deprived of their property. For instance, Middle Eastern and North African countries are reluctant to sign international conventions, such as the "Rome Law", as they believe that to do so would be interpreted as their acceptance of conditions they consider unacceptable, especially with regard to the extinction of the right to reclaim (Fraoua 2009).

Although in international law, the question of a time-bar on looting and the illegal removal of objects is the subject of debate, in each individual country, this legal institution is a pillar of the rule of law, as it contributes to the principle of legal certainty. The statute of limitations establishes the extinction of responsibility for the commission of unlawful acts after a given period of time, provided that no action is taken during that period to claim that responsibility. The statute of limitations for an offense is based on a set of moral judgments, such as the change in personality of the alleged perpetrator over time or the abatement of the social alarm. In Spain, the statute of limitations on the offenses of damage to archaeological sites and looting, which are provided for under Article 323 of the Código penal (Criminal Code), is ten years, according to Article 131 of the same legal text. In cases of smuggling and the illicit trade of antiquities, the statute of limitations is five years, in accordance with Article 3 of the Represión del Contrabando (Suppression of Smuggling Act [Organic Law 12/1995, of December 12]) (Rufino Rus 2018; Núñez Sánchez 2018).

The expiration of the statute of limitations entails the need to determine the date of commission, which, in the present case, often means knowing when the illegal excavation in which an artifact was found was carried out.

\subsection{Falsification of Provenience and Collecting History}

The importance given to this date is easier to understand when one bears in mind the overlap between the channels for the licit and illicit trade in antiquities, at least in the final stages. As already noted, the premise that an unknown or doubtful collecting history points to an illicit origin concealed by forged documentation is generally borne out by the facts. Indeed, those who currently trade in these types of objects have an interest in giving them the appearance of lawfulness. As explained in the previous sections, the end recipients have set up some barriers, but they are hardly insurmountable. While customs controls tend to be fairly exhaustive for exports, this is less true of imports, as, in the Spanish case, the Ministry of Culture itself has noted (González-Barandiarán y de Muller 2008).

If in the 1960s and 1970s, to acquire a piece of illicit origin, one needed only to resort to secrecy and to cloak its origin in ambiguous terms (Watson and Todeschini 2006), today it is necessary to assign the piece a fake origin based on forged documents or documents that are actually irrelevant to proving its legal origin, but which are unfortunately accepted as valid proof by the customs services of many countries. A paradigmatic example of this way of doing things is the certificates issued by the institutions that manage databases of stolen cultural goods, such as Art Loss Register. Such certificates are absolutely ineffective with regard to demonstrating the lawfulness of objects stolen directly from sites and of whose existence nothing had previously been known (Kaye 2009, p. 415; Reyes Mateo 2018).

Police investigations focus especially on cases of major works of art, in which it is relatively easy to find documentation and analyze whether the pieces have been forged. The museums involved have certain limits beyond which it is difficult to go. Cases such as those of Subhash Kapoor, Frederick Schultz, the Thomas Alcock collection, or minor objects auctioned by auction houses, such as Christie's or Sotheby's, show that forged documents are regularly used to give the impression of 
an authentic origin to works of art supplied to the world's leading museums (Kaye 2009, p. $413 \mathrm{ff}$.; Tabitha Neal 2014, p. 22; Tsirogiannis 2013, 2015; Lyons 2016, p. 249).

Only in cases involving special circumstances, such as the existence of witnesses of the looting or when the remains of a piece left at the site have been documented, is there virtually incontrovertible certainty of the provenience (O'Keefe 1997, p. 33). In this type of investigation where, moreover, according to the information seized from the alleged criminals, there is a dense network of intermediaries interacting with each other, as well as points of transit for stolen goods where they can easily be provided with forged documentation, the forensic archaeometry we hope to promote could play a pivotal role in the police investigation.

Here, it is worth recalling that, sometimes, the combination of documentary evidence and stylistic attributions proves to be erroneous in establishing a certain provenience. In short, despite the accomplishments achieved, the investigation of illicit trafficking uses tracing methodologies to establish provenience that are rooted in traditional techniques, such as stylistic studies, the compilation of news reports, or wire-tapping. The seizure by the Italian police of the Medici archive, as a result of the operation of the same name (Watson and Todeschini 2006), provided valuable information to claim pieces from museums and private collections. However, the possibilities have almost been exhausted and it has proven ineffective in cases of new pieces placed on the market, usually from war-torn Middle Eastern countries, especially Syria. Furthermore, Tsirogiannis (2016) has demonstrated that the mere presence of photographs in files seized by the Italian police from intermediaries and traffickers, in the first decade of this century, can lead to errors in the attribution of provenience. This would seem to be the case of the sculpture of the wife of Emperor Adrian, Vibia Sabina, returned by the Fine Arts Museum of Boston to the Italian government, which alleged the existence of photos of this work shortly after its clandestine find in the G. Medici archive, when it is now known that it is from Turkey.

\section{4. "Proof of Origin" in Spain}

The provision of the 1985 Ley del Patrimonio Histórico Español (Spanish Historical Heritage Act) on the creation of police units specialized in crimes against historical heritage did not begin to yield tangible results in the form of actual operations until the second half of the 1990s. However, it was not until even later, with Operation Tambora in 2002, that these operations began to acquire media and social importance. This and other subsequent actions focused on collections amassed over the course of decades, following an investigative strategy that led from the collectors or possible recipients of the objects to the looters themselves. The aim was to untangle the network of direct and brokered connections between the two groups in order to bring relevant charges regarding the commission of criminal offences (Morales Bravo de Laguna 2015; Guasch Galindo 2018).

It is no secret that this strategy has not had the desired effect in the courts. Operation Tambora itself, Operation Pitufo, Operation Tertis, Operation Dionisos, and Operation Carolina, for example, all resulted in acquittals, followed by the eventual restoration of the pieces to their possessors. These judicial setbacks are problematic, not only because of their impact in the media, but also because clearly something (or more than one thing) went wrong in the process, given that in many cases, the pieces' illicit origin was not in doubt (Rodríguez Temiño 2012).

The reason cited by judges when finding in favor of the defendants has been the lack of "proof of origin". In other words, unless the looter is caught in flagrante, police investigations face the challenge of individualizing the pieces affected by the crime. They must demonstrate their provenience in an illegally excavated site, as well as the date of that excavation, in order to discredit the adverse possession or other legal forms of acquisition or the non-expiration of the statute of limitations.

Additionally, criminal charges can hardly be brought with regard to other criminal behaviors associated with looting, such as illegal sales, if the illicit origin cannot be proven.

To avoid such pitfalls in the future, new forms of police investigation have been rolled out, a phenomenon known as the "Operation Tertis Effect" (Morales Bravo de Laguna 2015). The different police investigation units are required to document the place of provenience of the artifact 
(Guasch Galindo 2018, Reyes Mateo 2018). This means deploying human and technical resources in the field to carry out multiple actions, such as surveillances, tracking, and roadblocks, not to mention wiretapping and possible home searches. All of this takes place in an adverse criminal law context due to the low penalization of these crimes (Rufino Rus 2018). This new methodology was tested in Operation Badía, which, notwithstanding its bright prospects, following a painstaking investigation, ended in a plea bargain. It had no significant practical results and, therefore, possibly lacked the deterrent nature inherent to criminal proceedings.

Recently, in the context of Operation Quedada, conducted in 2016 (Guisasola Lerma 2017, p. 17), the aforementioned Brigada de Patrimonio Histórico (Historical Heritage Brigade) seized an Iberian-Roman limestone sculpture of a lion (2nd or 1st centuries BCE) that was going to be sold in Madrid. Following a study of the piece, it was possible to establish its provenience as the Asta Regia site (Cádiz), as well as its recent removal (it still had a layer of carbonates amalgamated with traces of soil). In Judgment 46/18 of Criminal Court No. 6 of Granada, of 13 February 2018, the judge ruled that the expert assessments were right, recognizing that the piece belonged in the public domain as it had been found after 1985. The parties who had attempted to sell it were found guilty of dealing in stolen objects.

However, circumstances that allow for such categorical expert opinions are not always available. In other cases involving trafficking in archaeological objects or the illegal receipt thereof, it is impossible to catch the looters in the act, as the action was committed prior to the acquisition of the objects by the broker or collector or the objects may even have originated in third countries. Furthermore, in the police records, the pieces that still bear traces of soil tend to be the least valuable; the ones most likely to be sold have usually been cleaned. Then there is underwater looting, where the chances of witnessing the act of looting itself are very small and all but governed by happenstance. In such cases, new ways of proving the origin of the pieces and an approximate discovery date are needed. Which brings us back to forensic archaeometry.

\section{New Analytical Methodologies to Tackle Old Challenges}

The Spanish and international procedural reality is characterized by a lack of standards of proof in keeping with the real possibilities offered by forensic archaeometry. Usually, the evidence must prove the object's illicit collecting history and provenience "beyond a reasonable doubt", an expression that, in any case, is imbued with a tautological character it lacks.

In our view, evidential reasoning should reflect actual practicable possibilities in order to ensure the accuracy of the information on which the case will be judged or that will serve as the basis for decisions. It is thus necessary to reflect on the standards and burdens of proof in these cases, both by reviewing the available techniques and through inquiries into new avenues of analysis and research.

The necessary documentary inquiry to establish the provenience and collecting history should not be considered, as it currently is, the sole and indispensable means of determining these data for archaeological pieces appearing on the market or seized in police operations.

As noted by Levine (2008, p. 232), "wherever the temporal benchmark is set, it is equally important that generally accepted standards be developed concerning the quality of documentation and substantial evidence that will be accepted in making the informed judgments that go into establishing provenance" (i.e., collecting history).

Often, techniques regularly used in other archaeological research, such as archaeometry, can be added, but historiographical studies can also be used to qualify the evidence provided by the documentation, where it exists, or to serve in its stead.

The limits of the evidentiary potential of each of these techniques should be tested, identifying the cases in which each one is most reliable, and determining when and why that is so. Law, the natural sciences (geology, biology, chemistry, and physics), criminology, and archaeology must be combined to contribute to the achievement of the overall objective through the achievement of osmotically-related partial goals in each field. 
Specifically with regard to Spain, the fact that archaeological excavations and chance finds have been happening since time immemorial entails the existence of an enormous accumulation of archaeological objects with different legal statuses in terms of possession or ownership. Some objects were found by chance or as a result of an archaeological inquiry when the laws governing these cases allowed the finder to claim ownership of the find. In other cases, especially following the passage of the 1985 Ley del Patrimonio Histórico Español (Spanish Historical Heritage Act), the affected objects became public property by operation of the law. In between these cases lies a wide range of circumstances that need to be carefully defined in accordance with the regulations in force at any given time and the place where the objects were found.

The passage of the 1911 Ley de Excavaciones Arqueológicas (Archaeological Excavations Act) entailed the establishment of "rules to govern archaeological, artistic, and scientific excavations and the conservation of ruins and antiquities" that changed the existing landscape. A legal framework was created to protect Spain's archaeological goods and their discovery, whether as a result of archaeological actions or chance finds. The first consequence was that all archaeological excavations had to be approved by the competent authority, which, according to the new regulatory provision, was the Junta Superior de Excavaciones Arqueológicas (Senior Committee for Archaeological Excavations), attached to the then Spanish Ministry of Public Instruction and Fine Arts. That body was responsible for granting excavation permits and receiving the reports on the work carried out. This law remained almost unchanged, except for minor amendments, until the passage of the aforementioned 1985 Ley de Patrimonio Histórico Español.

This means that the immense majority of legally authorized excavations throughout most of the 20th century should be documented. It is not unconceivable to think that the archival data could be checked against the databases of the museums in which the collections resulting from these excavations have been catalogued. Analyzing this documentation will help to identify those archaeological activities and finds carried out in accordance with the law in force at the time and thus to distinguish between them and those archaeological pieces whose legitimate possession is subject to serious doubts. In this regard, it is worth recalling the judgment of 14 April 1991, of the Third Section of the Contentious-Administrative Chamber of the Spanish Supreme Court. In reasoning the conditions that must be met for archaeological objects to be privately owned, prior to the entry into force of the Ley del Patrimonio Histórico Español, that judgment established that the actions resulting in the recovery of these objects, whether excavations or chance finds, had to have been carried out in accordance with the law in force at the time. Otherwise, in application of those same laws, the objects should be confiscated. This would thus be one initial filter, which, although not unassailable, is enormously useful in disproving certain claims of adverse possession unsupported by legally valid proof.

Issues related to the provenience of archaeological objects have been explored in detail in archaeological research. However, there remains a lack of effective protocols to enable their sufficient characterization and to determine their provenience, if not the exact site, then at least a more or less delimited area. To this end, the main geological and biological parameters that could be used for such characterizations should be defined (Gansell et al. 2014; Oonk and Spijker 2015). From a technical perspective, the application of new computer methodologies for indexing, data mining, and smart queries can be used in contexts in which looting and illicit trafficking are carried out, as well as to facilitate the establishment of the area of provenience of an object.

This approach should be combined with archaeological research itself. Such research should be used to check the archaeometric data against the knowledge of prehistoric or ancient trade. This would also help to strengthen the case for ruling out alleged proveniences of unlikely objects that are incongruent with what is known from the documented commercial dynamics typical of their historical context. There is extensive and reliable academic information on these aspects, but it has not been systematized, summarized, or organized in a way that makes it accessible to forensic practice. This knowledge could serve as an argument to rule out unlikely proveniences, question unusual ones, or ratify those known as a result of archaeological research. This, in conjunction with other aspects, 
such as the type and style of an object, could add considerable weight to the reasoning employed in expert evidence.

Undoubtedly, the most experimental and novel challenge will be to verify the time that has elapsed since an object's discovery. It is not easy to establish one or more techniques that will yield the desired results. The most promising method to date seems to be the study of the evolution of colonies of microorganisms, along with the different compounds they excrete in different environmental conditions. To this end, research on the activity of bacterial communities at archaeological sites has found that the structure of the community is different in zones that have been tampered with and zones that have not (Xu et al. 2017). For now, research on terrestrial bacterial communities is linked to ecological studies. Experimental lines of work exist on their evolution over time (Shade et al. 2013; Fiegna et al. 2015), but without a particular interest in the establishment of a "time curve", which would be the valid objective for forensic archaeometry. All of this offers a glimmer of hope for the opening of a new field of archaeometric research with the necessary focus to be of use in the investigation of the looting and illicit trafficking of antiquities. The research projects mentioned at the start of this paper aim to advance in this direction.

However, whatever the final outcome of this scientifically experimental stage, the findings will ultimately need to be incorporated in police and judicial practice. If, as we hope, the outcome is reasonably positive, police crime labs would have to include the new techniques in their investigation protocols. Thus, one of the premises we are working with in the projects is that the developed techniques must not be burdensome or require costly equipment to be performed.

Should these experimental inquiries prove to be inconclusive, a discussion should be started on the types of expert opinions and standards of proof likely to be required to ensure sufficient conviction regarding the acts being investigated and tried. This is especially true in those cases involving additional evidence, even if not definitive, concerning the illicit origin of pieces, at least in jurisdictions such as Spain, in which archaeological activity and chance finds have been regulated by law for more than a century.

Finally, as is well known, even in countries in which property rights are conceived of more broadly, archeological objects are subject to a special legal regime ratione materiae, distinct from the law governing other objects considered part of cultural heritage. This distinction is due to certain defining traits: First, the fact that they are often hidden and unknown, with no known owner at the time of their discovery; and second, their historical ties to a broad group of people, a group that grows even broader the further one travels into the past, although this latter trait still does not justify the removal of unique pieces from their present-day state. The fact that many countries, such as Greece, Italy, Morocco, Egypt, or Spain, have placed archaeological heritage in the public domain and, therefore, removed it from the private legal trade is a clear safeguard for its integrity.

Within Spain, in Andalusia, the regional law governing historical heritage, passed in 2007, also established a period for the legalization of private collections of archaeological artifacts that had not previously been legal. Beyond that period, they would be presumed to be in the public domain. Although this presumption of law is logically iuris tantum (rebuttable), in recent cases involving seized goods, it has been invoked to legitimize their court-ordered turning over to the Andalusian cultural authorities.

However, its potential is hampered by the type of crime that usually affects these types of objects. Often, the destination is an international market, and the perpetrators go to great lengths to conceal the objects for years in order to prevent them from being traced. This situation is not easy to tackle: The different legal regimes for the ownership of archaeological artifacts can make it very difficult to effectively intervene when situations of illicit trafficking are discovered. This is because of the wide variety of jurisdictions that can be applied under the general lex rei sitae conflict-of-laws rule. Consequently, detailed consideration should be given to the possibility of extending the placement of archaeological objects in the public domain via international authorities, in order to establish the 
practice in a large number of countries that have not yet taken such a step. That would enable broader application of the lex originis rule.

If, in addition, a sufficiently broad transitional period were to be established, in which such objects in the possession of natural or legal persons were allowed to surface in order to further knowledge thereof by the public sector, within a relatively acceptable period of time, the panorama with regard to the international trafficking of archaeological objects could change dramatically.

There is little doubt that the antiquities market is beginning to be flooded with goods from regions that have been embroiled in armed conflict for years, often the product of clandestine digs. International and domestic legal measures, of both a criminal and an administrative or civil nature, can be used more effectively if the evidence is less assailable and if we grant a special legal status to archaeological heritage separate from ordinary legal trade. In any case, the investigation of this type of crime must not continue to be the sole purview of police, criminologists, or archaeologists. Interdisciplinary teams and research projects are required to facilitate this goal. Professionals involved in the fight against the illicit trafficking of antiquities must renew our conceptual and operational arsenal. In some cases, we must innovate with scientific techniques; in others, we must research methodologies that are already fully operational in archaeology or develop new techniques for tackling the challenges of evidentiary action.

Finally, this activity must also include advocacy for the internationalization of legal regimes that facilitate the transmission to future generations of a set of objects whose purpose is both to serve as a means for us to recognize ourselves as societies that share a common past and to revitalize the social fabric into which they are inserted. These functions are truncated by the looting and relocation caused by illicit trafficking.

Author Contributions: Conceptualization, I.R.T. and A.Y.; Methodology, S.E.J.-V. and Á.R.M.; Validation, J.R.R.; Resources, J.S.Á. and A.C.L.B.; Investigation, I.R.T., A.Y., S.E.J.-V.; Writing-Original Draft Preparation, I.R.T.; Writing Review \& Editing, I.R.T.

Funding: This paper was made possible by R\&D Project, DER2016-74841-R: “Instrumentos jurídicos en defensa de la integridad de los bienes arqueológicos" [Legal Instruments in Defense of the Integrity of Archaeological Heritage] funded by the Spanish Ministry of Economy and Competitiveness for the 2017-2019 period.

Conflicts of Interest: The authors declare no conflict of interest.

\section{References}

Armbrüster, Christian, Pascal Beauvais, Jihane Chedouki, M. Marie Cornu, Élisabeth Fortis, Manlio Frigo, Jérôme Fromageau, Antoinette Maget-Dominice, Vincent Negri, and Marc-André Renold. 2011. Study on Preventing and Fighting Illicit Trafficking in Cultural Goods in the European Union. Final Report: October 2011. Brussels: European Commission.

Association of Art Museum Directors. 2013. Guidelines on the Acquisition of Archaeological Material and Ancient Art. Available online: https://www.aamd.org/sites/default/files/document/AAMD\%20Guidelines\% 202013.pdf (accessed on 16 November 2017).

Belzic, Morgan. 2017. Les sculptures funéraires de Cyrénaïque sur le marché de l'art. Libyan Studies 48: 105-16. [CrossRef]

Bendala Galán, Manuel, Ignacio Rodríguez Temiño, and Esther Núñez Pariente de León. 1993. Una nueva estela de guerrero tartésica de la provincia de Córdoba. In Homenaje a José María Blázquez. Edited by Javier Alvar Ezquerra and Julio Mangas Manjarrés. Madrid: Ediciones Clásicas, vol. 2, pp. 59-70.

Boardman, Jhon. 2006. Archaeologists, Collectors, and Museums. In Who Owns Objects? The Ethics and Politics of Collecting Cultural Artifacts. Edited by Eleanor Robson, Luke Treadwell and Chris Gosden. London: Oxbow Books, pp. 33-46.

Bower, Nathan W., Jonathan O. Speare, and William J. Thomas. 1993. Applications of X-RAY Fluorescence-Pattern Recognition in Forensic Archaeometry and Archaeomaterials Analyses. The Rigaku Journal 10: 10-21. 
Brodie, Neil. 2006. An Archaeologist's View of the Trade in Unprovenanced Antiquities. In Art and Cultural Heritage: Law, Policy, and Practice. Edited by Barbara T. Hoffman. New York: Cambridge University Press, pp. 52-64.

Brodie, Neil. 2011. Congenial Bedfellows? The Academy and the Antiquities Trade. Journal of Contemporary Criminal Justice 27: 408-37. [CrossRef]

Brodie, Neil. 2015a. Archaeological and Criminological Approaches to studying the antiquities trade: A comparison of the Illicit Antiquities Research Centre and the Trafficking Culture Project. Cuadernos de Prehistoria y Arqueología de la Universidad de Granada 25: 99-105.

Brodie, Neil. 2015b. The Internet Market in Antiquities. In Countering Illicit Traffic in Cultural Goods. The Global Challenge of Protecting the World's Heritage. Edited by France Desmarais. Paris: ICOM, pp. 11-20.

Brodie, Neil, and Blyth Bowman Proulx. 2014. Museum Malpractice as Corporate Crime? The Case of the J. Paul Getty Museum. Journal of Crime and Justice 37: 33-46. [CrossRef]

Brodie, Neil, Jenny Doole, and Peter Watson. 2000. Stealing History: The Illicit Trade in Cultural Material. Cambridge: McDonald Institute.

Brodie, Neil, and Colin Renfrew. 2005. Looting and the World's Archaeological Heritage: The Inadequate Response. Annual Review of Anthropology 34: 343-361. [CrossRef]

Canto García, Alberto, and José María de Francisco Olmo. 2006. VICO MONTEOLIVA, Jesús; CORES GOMENDIO, $M^{a}$. Cruz y CORES URÍA, Gonzalo. Corpus Nummorum Visigothorum. 575-714. Leovigildus-Achila, Madrid, 2006, pp. 726. ISBN: 84-609-8913-5. Revista General de Información y Documentación 16: 253-58.

Chippindale, Christopher, and David W. J. Gill. 2000. Material Consequences of Contemporary Classical Collecting. American Journal of Archaeology 104: 463-511. [CrossRef]

Coggins, Clemency Chase. 1998. United States cultural property legislation: Observation of a combatant. International Journal of Cultural Property 7: 52-68. [CrossRef]

Cuno, James. 2007. Art Museums, Archaeology, and Antiquities in an Age of Sectarian Violence and Nationalist Politics. In The Acquisition and Exhibition of Classical Antiquities. Professional, Legal, and Ethical Perspectives. Edited by Robin F. Rhodes. Notre Dame: University of Notre Dame Press, pp. 9-26.

Curtis, Neil G. W. 2006. Universal museums, museum objects and repatriation: The tangled stories of things. Museum Management and Curatorship 21: 117-27. [CrossRef]

DIVUM. 2004. Declaration on the Importance and Value of Universal Museums. ICOM News 1: 4.

Edwards, Howell, and Peter Vandenabeele, eds. 2012. Analytical Archaeometry: Selected Topics. Cambridge: The Royal Society of Chemistry.

Enríquez Navascués, Juan Javier, and Francisco González Jiménez. 2005. Arqueología y Defensa del Patrimonio. La experiencia del Grupo de Delitos contra el Patrimonio Histórico de Extremadura. Complutum 16: $33-57$.

Farchakh-Bajjaly, Joanne. 2008. Who Are the Looters at Archaeological Sites in Iraq? In Antiquities under Siege: Cultural Heritage Protection after the Iraq War. Edited by Lawrence Rothfield. Walnut Creek: AltaMira Press, pp. 49-56.

Felch, Jason, and Ralph Frammolino. 2011. Chasing Aphrodite. The Hunt for Looted Antiquities at the World's Richest Museum. Boston: Houghton Mifflin Hardcourt.

Fernández Gómez, Fernando. 1996. De excavaciones clandestinas, mercado de antigüedades y publicación de 'hallazgos'. Complutum Extra 6: 283-94.

Fiegna, Francesca, Alejandra Moreno-Letelier, Thomas Bell, and Timothy G. Barraclough. 2015. Evolution of species interactions determines microbial community productivity in new environments. The ISME Journal 9: 1235-45. [CrossRef] [PubMed]

Fincham, Derek. 2013. The Parthenon Sculptures and Cultural Justice. Fordham Intellectual Property, Media E Entertainment Law Journal 23: 943-1016.

Fraoua, Rhida. 2009. Prévention et lutte contre le trafic illicite de biens culturels. Atelier régional Beyrouth, Liban, 9-11 November 2009, Rapport de synthèse. London: UNESCO et Euromed. Available online: http://www.euromedheritage.net/euroshared/doc/Rapport $\% 20 \mathrm{de} \% 20$ synth $\%$ C3\% A8se\%20Atelier\%20de\%20Beyrouth.pdf (accessed on 15 May 2016).

Frulli, Micaela. 2011. The Criminalization of Offences against Cultural Heritage in Times of Armed Conflict: The Quest for Consistency. The European Journal of International Law 22: 203-17. [CrossRef]

Fuentes Camacho, Víctor. 1994. El tráfico ilícito internacional de bienes culturales. Madrid: Beramar. 
Gansell, Amy Rebeca, Jean-Willem van de Meent, Sakellarios Zairis, and Chris H. Wiggins. 2014. Stylistic clusters and the Syrian/South Syrian tradition of first-millennium BCE Levantine ivory carving: A machine learning approach. Journal of Archaeological Science 44: 194-205. [CrossRef]

Gerstenblith, Patty. 2003. Adquisition and Deacquisition of Museum Collections and the Fiduciary Obligations of Museums to the Public. Cardozo Journal of International and Comparative Law 11: 409-65.

Gill, David W. J., and Christopher Chippindale. 1993. Material and intellectual consequences of esteem for Cycladic figures. American Journal of Archaeology 97: 601-59. [CrossRef]

Gollin, Jane. 1974. A Museum Applauds the Dealers. Journal of Field Archaeology 1: 391-92.

Gómez López, Ana Belén. 2014. Fondo documental asociado al Farmm. In Fondo Arqueológico Ricardo Marsal Monzón. Sevilla: Junta de Andalucía, pp. 67-84.

González-Barandiarán y de Muller, Carlos. 2008. Importación y exportación de bienes culturales. In La lucha contra el tráfico ilícito de Bienes Culturales (Madrid, 2006). Madrid: Ministerio de Cultura, pp. 117-22.

Goodall, Rosemary A. 2012. Identification and Authentication. In Analytical Archaeometry: Selected Topics. Edited by Howell Edwards and Peter Vandenabeele. Cambridge: The Royal Society of Chemistry, pp. 483-500.

Guasch Galindo, Juan Antonio. 2018. La Guardia Civil y su lucha contra el expolio arqueológico terrestre. In El expoliar se va a acabar. Uso de detectores de metales y arqueología: Sanciones administrativas y penales. Edited by Ana Yáñez and Ignacio Rodríguez Temiño. Valencia: Tirant lo Blanch, pp. 359-98.

Guisasola Lerma, Cristina. 2017. Delitos contra bienes culturales: Una aproximación al concepto de expolio en el Derecho Penal. Revista General de Derecho Penal 27: 1-28.

Gutiérrez Zarza, Ángeles. 2017. Tráfico ilícito de bienes culturales y cooperación penal europea e internacional. Madrid: Centro de Estudios Jurídicos.

Hunter, John, and Margaret Cox, eds. 2005. Forensic Archaeology: Advances in Theory and Practice. London: Routledge.

Kaye, Lawrence M. 2009. Provenance Research: Litigation and the Responsability of Museums. In Cultural Heritage Issues: The Legacy of Conquest, Colonization, and Commerce. Edited by James A. R. Nafzinguer and Ann M. Nicgorski. Leiden: Brill, pp. 405-20.

Lazari, Antonio. 2018. El método comparativo y el nuevo paradigma de protección de los bienes culturales ante las situaciones iraquí y siria. In Expolio de bienes culturales. Instrumentos legales frente al mismo. Directed by Cristina Guisasola Lerma. Valencia: Tirant lo Blanch, pp. 89-152.

Levine, Jane A. 2008. The Importance of Provenance Documentation in the Market for Ancient Art and Artifacts: The Future of the Market May Depend on Documenting the Past. DePaul Journal of Art, Technology $\mathcal{E}$ Intellectual Property Law 19: 219-33.

Lyons, Claire L. 2016. On Provenance and the Long Lives of Antiquities. International Journal of Cultural Property 23: 245-53. [CrossRef]

Mackenzie, Simon. 2011. The Market as Criminal and Criminals in the Market: Reducing Opportunities for Organized Crime in the International Antiquities Market. In Crime in the Art and Antiquities World: Illegal Trafficking in Cultural Property. Edited by Stephano Manacorda and Ducan Chappell. New York: Springer, pp. 69-86.

Manacorda, Stephano. 2009. Introduction. In Organised Crime in Art and Antiquities. Edited by Stephano Manacorda. Milano: ISPAC, pp. 17-29.

Manacorda, Stephano. 2011. Criminal Law Protection of Cultural Heritage: An International Perspective. In Crime in the Art and Antiquities World: Illegal Trafficking in Cultural Property. Edited by Stephano Manacorda and Ducan Chappell. New York: Springer, pp. 17-48.

Marlowe, Elizabeth. 2016. What We Talk About When We Talk About Provenance: A Response to Chippindale and Gill. International Journal of Cultural Property 23: 217-36. [CrossRef]

Merryman, John H. 1994. The Nation and the Object. International Journal of Cultural Property 3: 61-76. [CrossRef]

Merryman, John H. 2000-2001. Cultural Property, International Trade and Human Rights. Cardozo Journal of International and Comparative Law 19: 51-67.

Morales Bravo de Laguna, Javier. 2015. La Guardia Civil y la lucha contra el expolio arqueológico. Cuadernos de Prehistoria y Arqueología de la Universidad de Granada 25: 31-48.

Muscarella, O. W. 1977. 'Ziwiye' and Ziwiye: The Forgery of a Provenience. Journal of Field Archaeology 4: 196-219.

Muscarella, Oscar White. 2009. The Fifth Column Within the Archaeological Realm: The Great Divide. In Studies in Honor of Altan Çilingiroglu. A Life Dedicated to Urartu on the Shores of the Upper Sea. Edited by Haluk Saglamtinmur. Istanbul: Arkeoloji ve Sanat Yayinlari, pp. 395-406. 
Myren, Robin Short. 2010. Provenance Factors for Antiquities Acquisitions. Society for California Archeology Proceedings 24: 1-3.

Nafziger, James A. R. 1983-1984. The New International Legal Framework for the Return, Restitution or Forfeiture of Cultural Property. New York University Journal of International Law and Politics 15: 789-814.

Núñez Sánchez, Ángel. 2018. La nueva regulación penal del delito de expolio de yacimientos arqueológicos. In Expolio de Bienes Culturales. Instrumentos Legales Frente al Mismo. Directed by Cristina Guisasola Lerma. Valencia: Tirant lo Blanch, pp. 154-86.

Ojeda Calvo, Reyes. 2014. Proyecto Farmm: Actuaciones para el conocimiento, la conservación y el estudio de un fondo arqueológico excepcional. In Fondo Arqueológico Ricardo Marsal Monzón. Sevilla: Junta de Andalucía, pp. 9-26.

O'Keefe, Patrick. 1997. Trade in Antiquities: Reducing Destruction and Theft. Paris: Unesco and Archetype Publications.

Oonk, Stijn, and Job Spijker. 2015. A supervised machine-learning approach towards geochemical predictive modeling in archaeology. Journal of Archaeological Science 59: 80-88. [CrossRef]

Ortiz, George. 1994. In Pursuit of the Absolute: Art of the Ancient World from George Ortiz Collection. Berne: Bentelli-Werd.

Pegoraro, Lucio. 2013. Derecho nacional, derecho internacional, derecho europeo: La circulación horizontal y vertical entre formantes. Anuario Iberoamericano de Justicia Constitucional 17: 257-86.

Price, T. Douglas, and James H. Burton. 2011. An Introduction to Archaeological Chemistry. New York: Springer.

Pye, Kenneth. 2007. Geological and Soil Evidence Forensic Applications. Boca Raton: CRC Press.

Renfrew, Colin. 1991. The Cycladic Spirit. London: Thames and Hudson Ltd.

Renfrew, Colin. 2000. Loot, Legitimacy and Ownership. Ethical Crisis in Archaeology. London: Duckworth.

Reyes Mateo, Álvaro. 2018. El expolio arqueológico en España. In El expoliar se va a acabar. Uso de detectores de metales y arqueología: Sanciones administrativas y penales. Edited by Ana Yáñez and Ignacio Rodríguez Temiño. Valencia: Tirant lo Blanch, pp. 399-410.

Rhodes, Robin F., ed. 2007. The Acquisition and Exhibition of Classical Antiquities. Professional, Legal, and Ethical Perspectives. Notre Dame: University of Notre Dame Press.

Rodríguez Temiño, Ignacio. 2012. Indianas jones sin futuro. La lucha contra el expolio del patrimonio arqueológico. Madrid: JAS Arqueología SLU.

Rosenberg, Charles. 2007. Response to James Cuno. In The Acquisition and Exhibition of Classical Antiquities. Professional, Legal, and Ethical Perspectives. Edited by Robin F. Rhodes. Notre Dame: University of Notre Dame Press, pp. 27-30.

Rufino Rus, Javier. 2018. La tutela del patrimonio arqueológico en el Código Penal. Evolución normativa y jurisprudencial. Deficiencias y propuestas; la situación tras la reforma de la L.O. 1/2015. In El expoliar se va a acabar. Uso de detectores de metales y arqueología: sanciones administrativas y penales. Edited by Ana Yáñez and Ignacio Rodríguez Temiño. Valencia: Tirant lo Blanch, pp. 467-510.

San Martín Calvo, Marina. 2016. La sanción penal internacional de los crímenes de guerra contra los bienes culturales. El asunto “Ahmad al-Mahdi”. Revista Española de Estudios Internacionales 8: 218-51.

Scovazzi, Tulio. 2015. Evolutionary Trends as Regards the Return of Removed Cultural Property. In El tráfico de bienes culturales. Edited by Luis Pérez-Prat Durbán and Antonio Lazari. Valencia: Tirant lo Blanch, pp. 20-90.

Shade, Ashley, J. Gregory Caporaso, Jo Handelsman, Rob Knight, and Noah Fierer. 2013. A meta-analysis of changes in bacterial and archaeal communities with time. The ISME Journal 7: 1493-506. [CrossRef] [PubMed]

Slayman, Andrew. 1998. Recent Cases of Repatriation of Antiquities to Italy from the United States. International Journal of Cultural Property 7: 456-63. [CrossRef]

Subkowski, Peter. 2006. On the psychodynamics of collecting. The International Journal of Psychoanalysis 87: $383-401$. [CrossRef] [PubMed]

Tabitha Neal, Jody. 2014. Provenience, Provenance and the UNESCO 1970 Convention: Two Schools of Thought on the Publication of Indeterminate Artifacts. Middle East-Topics \& Arguments 3: 19-28.

Thomasson, Fredrik. 2010. Justifying and Criticizing the Removals of Antiquities in Ottoman Lands: Tracking the Sigeion Inscription. International Journal of Cultural Property 17: 493-517. [CrossRef]

Tsirogiannis, Christos. 2013. Something is Confidential in the State of Christie's. In Art Crime. Berlin: Springer, pp. 3-20.

Tsirogiannis, Christos. 2015. Mapping the supply: Usual suspects and identified Antiquities in 'reputable' auction houses in 2013. Cuadernos de Prehistoria y Arqueología de la Universidad de Granada 25: 107-44. 
Tsirogiannis, Christos. 2016. False Closure? Known Unknowns in Repatriated Antiquities Cases. International Journal of Cultural Property 23: 407-31. [CrossRef]

Watson, Peter, and Cecilia Todeschini. 2006. The Medici Conspiracy. The Illicit Journey of Looted Antiquities from Italy's Tomb Raiders to the World's Greatest Museums. New York: PublicAffairs.

Wessel, Günther. 2015. Dealers, Collectors, Provenances and Rights: Searching for Trace. In Countering Illicit Traffic in Cultural Goods. The Global Challenge of Protecting the World's Heritage. Edited by France Desmarais. Paris: ICOM, pp. 1-10.

Wiseman, James. 1984. Scholarship and Provenience in the Study of Artifacts. Journal of Field Archaeology 11: 67-77.

Xu, Jinjin, Yanfei Wei, Hanqing Jia, Lin Xiao, and Decai Gong. 2017. A new perspective on studying burial environment before archaeological excavation: Analyzing bacterial community distribution by high-throughput sequencing. Scientific Reports 7: 41691. [CrossRef] [PubMed]

Yañez, Ana, and Ignacio Rodríguez Temiño, eds. 2018. El expoliar se va a acabar. Uso de detectores de metales y arqueología: Sanciones administrativas y penales. Valencia: Tirant lo Blanch.

(C) 2018 by the authors. Licensee MDPI, Basel, Switzerland. This article is an open access article distributed under the terms and conditions of the Creative Commons Attribution (CC BY) license (http:/ / creativecommons.org/licenses/by/4.0/). 